HStud 25 (2011)1, 3-24

DOI: 10.1556/HStud.25.2011.1.1

\title{
ENVISIONING OR EFFACING THE OTHER: DIFFERENT APPROACHES TO TRANSLATION IN THE ENGLISH AND HUNGARIAN LITERARY TRADITIONS
}

\author{
THOMAS COOPER \\ Eszterházy Károly College \\ Eger, Hungary
}

\begin{abstract}
Though rarely made a subject of study, methods of literary translation may well reveal a great deal about the cultures in which they are practiced. In the case of the English canon, the prevalence of domesticating translation can be interpreted as an expression of the confidence of a colonial culture in the adequateness of its language as a means of universal expression. The use of translation as a means of introducing elements of style foreign to the target language in the Hungarian literary tradition, in contrast, suggests a culture more self-conscious of the particularity of its culture. A comparison of divergent approaches to translation in the Hungarian and English literary traditions offers a critical perspective from which to consider the self-conceptions of the two cultures.
\end{abstract}

Keywords: translation, Hungarian literature, canon, fidelity, domesticating translation, foreignizing translation, discursive practices

The general absence of issues of translation from curricula in the humanities at colleges and universities in the United States and Europe, whether through the unquestioned acceptance of translations as adequate substitutes for originals in courses on Western or world literature or the categorical dismissal of translations as inferior in courses on national literatures taught in languages other than English, implies an understanding of translation itself as a practice the aims and methods of which are uniformly agreed upon and self-evident. A comparative study of translation in the English and Hungarian literary traditions, however, suggests a view of translation not as disinterested or consistent across cultures, but rather culturally situated and divergent in methods and functions. Whereas in the English tradition over the past four centuries the value of a translation has been measured by its conformity to the conventions of the target-language literature, since the early 19th century the Hungarian tradition has shown recognition of the value of translation as a means of introducing new forms and conceptions of literature. Notable exceptions notwithstanding, in English literature a translation has only 
been successful if it has managed to efface on the level of style its status as a translation. In the Hungarian tradition, in contrast, many celebrated literary translations, far from showing little trace of the foreign, functioned as alibis for the introduction of elements alien to prevailing literary discursive practices, thereby announcing rather than concealing their status as translations. Seen in a comparative context, translation itself, both as articulated in theory and as practiced, emerges not as a monolithic pursuit based on consensus across cultures or allegedly self-evident norms and goals, but rather a culturally and historically situated product, and as such, a cause and effect of a culture's strivings to define and represent itself. In the case of the comparative study of English and Hungarian literature, differing views of the roles of translation can be interpreted as manifestations of the very different circumstances and self-conceptions of the two literary cultures, one the literature of an imperial, colonizing power, the other the literature of a language community situated within a multi-lingual empire. The domesticating translation characteristic of the English (and American) tradition arguably reflects a complacency typical of (and functional in) a colonial culture, while the innovative translation by no means foreign to the Hungarian tradition suggests acknowledgment of the possibility of genuine otherness, an otherness to be preserved or mimicked in the act of translation.

As translation scholar and theorist Lawrence Venuti (1995) has argued, since the late early modern period translation into English has been marked by the tendency towards domestication, in other words the privileging of discourse that avoids calling attention to itself by submitting entirely to prevailing norms and tastes. Citing a diverse array of texts, from the translations and critical writings of 17th century poets John Denham and John Dryden to translations into English of works by 20th century poets and reviews of these translations, Venuti traces the rise of fluency in translation as the measure of value and even guarantor of accuracy. The texts on which he draws are often striking for the categoricalness of their language and the apparent assumption of the self-evidence of their (heavily value laden) terms. A citation from the writings of John Denham exemplifies the view according to which the task of the translator is to assimilate the foreign text to the contemporary national canon:

If Virgil must needs speak English, it were fit he should speak not only as a man of this Nation, but as a man of this age (cited in Venuti, $50)$.

As Venuti observes (and documents with copious examples), for the next three centuries fluency continued to function as the almost uncontested standard of value, allowing for the denial of genuine difference between source and target language cultures by effecting an effacement of traces of foreignness from the trans- 
lated text. Edward Fitzgerald's translation of the "Rubaiyat of Omar Khayyam" offers a notorious case in point. Fitzgerald transformed the verses of the Persian polymath into a musing on earthly pleasures with decidedly Christian overtones, using the word "paradise," for instance, where later translators used "kingdom of a Sultan" (Edward Heron-Allen) and "Sultan's realm" (Peter Avery and John Heath-Stubbs). He justifies his interpretive choices with his comment, as infamous as the translation itself, on the "amusement" of taking liberties with the works of "these Persians, who ... are not Poets enough to frighten one from such excursions, and who really do want a little art to shape them" (cited in Lefevere, 80).

Beyond simply precluding the introduction of values and poetics foreign to the target language culture, domesticating translation reinforces existing hegemonies within the target language, serving to maintain the illusion of language as a product and reflection of consensus instead of a site of contestation between different social factions. Fluency, in other words, is perhaps less a matter of neutralizing the potential threat of the foreign, which could always be dismissed as exotic, than it is a matter of neutralizing any threat to established hierarchies by confirming, through the reproduction of the familiar in the guise of the foreign, the social, cultural, and national attitudes and values of the educated elites. Merely by suggesting the possibility of transfer, translation emphasizes the communicative function of language, somewhat obscuring its own role in the performative enactment of contested discursive practices and the social meanings they embody. The heavily expurgated translations of the poetry of Catullus by Charles Lamb, for instance, offer an affirmation of Victorian attitudes concerning the vices of excess and the virtues of restraint. In his preface Lamb cites Dryden's view of the responsibility of the translator "to make his author appear as charming as he can" (lix). He renders Catullus more palatable for his anticipated readership by translating the explicit reference to homosexual acts in the first line of Catullus' apology for his love poetry ("Pedicabo ego et irrumabo"), for instance, into an accusation of implicitly heterosexual profligacy (discussed in detail, including comparisons with the translations by John Nott, in Venuti, 81-89). Matthew Arnold, remonstrating against the adoption of stylistic features of the ballad in translations of Homer, buttresses his notion of culture as the antidote to anarchy by offering alternative renderings intended to maintain the "nobleness" of the Greek poet by avoiding the use of "over-familiar" phrases, such as Chapman's "poor wretched beasts," or "ballad-slang," such as Maginn's "And scarcely had she begun to wash / Ere she was aware of the grisly gash" $(49,51)$. The social implications of Arnold's attempt to save the Iliad from the vulgarity of a folk genre are apparent in his repeated insistence (over fifty times in the course of his lectures) on the "nobleness" and "noble" quality of Homer's verse, terms that refer metaphorically to an abstract concept, but literally to a hereditary caste. And one might think finally of the 
use of the terms "parapraxis" and "cathexis" as translations of "Fehlleistung" and "Besetzung" by James Strachey in an attempt to confer the prestige of technical terminology on the works of Sigmund Freud (discussed in detail in Bettelheim, 84).

As these examples illustrate, when considering questions of translation, rather than speak of source and target languages it would be more precise to speak of source and target discourses within languages. Strachey's translation does not safeguard the English language from a threat posed by the importation of something foreign. Rather, it bolsters the stature of a particular genre of writing within English and maintains a hierarchy of value in which the "cultural" always figures beneath the "scientific." But this hierarchy is specific to English and American culture, and a translator of Freud into a language other than English may see no need to adopt a scientific style or introduce neologisms. A reader of English and Hungarian may not immediately realize, for instance, that Rossz közérzet a kultúrában (which could be translated as "malaise in culture") is the Hungarian title of Freud's Das Unbehagen in der Kultur, translated by Strachey as Civilization and its Discontents. Literary translation should not be understood simply as the transfer of a text from one language to another, but rather as the transfer of a text from the discursive practices demarcated, however provisionally or contentiously, as literature in one language to the discursive practices demarcated (provisionally, contentiously) as literature in another. In the case of the translation of poetry from English into Hungarian or Hungarian into English, for instance, it may not make sense to speak of English or Hungarian as self-evident wholes, but rather to keep in mind that we are considering specific sets of practices within these languages through which the notion of literature as a specific form of writing is asserted, reified, or, when the practices are contravened or abandoned, contested.

With the decline of emphasis on formal devices in English and American literature since the last decades of the 18th century, fidelity in translation has been increasingly posited as an alleged fidelity to content rather than form. It would be overly bold to identify a specific moment at which the notion of content began to assume more prominence than form in English literature, but the publication of the Preface to the Lyrical Ballads in 1800 offers a convenient date and Wordsworth's characterization of good poetry as "the spontaneous overflow of powerful feelings" a pithy formula for the standard by which much poetry was to be evaluated for the next two centuries. This shift has been accompanied by a change in attitudes towards translation as well, as translators have sought to preserve what was increasingly regarded as the essential content of a poem and avoid any overly conspicuous stylistic device that might undermine the impression of spontaneous overflow. As Robert Wechsler observes, 


\begin{abstract}
throughout most of literary history it was to the original poem's form that most translators felt they owed their fidelity. But from the late seventeenth century on, form grew less and less important, and content reared its head higher and higher. [...] Then translators began to use the form they chose and to preserve as much content as possible. The most popular choice in America today - of free verse in the translation of formal poetry - throws out poetic form (74).
\end{abstract}

Indeed the acceptance of fidelity to (alleged) content over form as an ethical obligation rather than an artistic value has been so complete that it has somewhat obscured its historical origins, and as Wechsler notes, one may forget that the Roman's fidelity to Greek forms, Dryden and Pope's use of heroic couplets in translations of Virgil and Homer, and Voltaire's imposition of classical rules on Shakespeare were as little questioned in their day as the contemporary conception of fidelity as fidelity to content is today (72).

Wechsler's conclusions, however, contain an element of contradiction. He is undoubtedly correct in his contention that "our culture ... has turned its back on artistic form as a form of artifice, as something false" (76), a process in which the Preface to the Lyrical Ballads constitutes a significant early milestone. But if this is the case, the translator's fidelity to form over content is not a fidelity to the meaning of the foreign text so much as a fidelity to the conventions of the target language literature and an affirmation and reproduction of a poetic ethos of 19th and 20th century English and American literary culture. By alleging fidelity to content the translation appears to fulfill an ethical obligation rather than conform to artistic conventions, purportedly offering an "honest" rendering of the original undistorted by the stylistic artifice of obtrusive elements of form, but the very notion of elements of form as evidence of artifice and distortion is itself part of the heritage of the European Romantic tradition and the English and American literary traditions in particular (one thinks of Wordsworth and John Stuart Mill in England and Emerson and Whitman in the United States). The appeal to the primacy of content as an explanation for the failure to (attempt to) translate form is nothing more (or less) than an assertion of the adequacy of a culturally specific value and practice to the interpretation (through translation) of texts originating in other cultures.

Fidelity to content functions as more, however, than a means of providing a covert verification of the values of the target language culture or a justification for the assimilation of the foreign text to an English stylistics centered on (the impression of) lack of artifice. An assertion of the existence of meaning separate from form, it implies the transparency and hence irrelevance of the substance of language, reducing words (poems, novels) to mere instruments for the representation of an unequivocal reality, a reality reproduced with entire adequacy by the transla- 
tion. As such, it is a product of and a tool in the construction and maintenance of an imperial vision of the world, imperial because it presents itself as objective, prior to and independent of any interpretive act, and hence uncontestable. A translation figures not as a representation of another work of literature, but as a representation of the content of another work of literature. Crucially, the notion of content itself is rarely interrogated. Its value lies precisely in its self-evidence. The translation of texts in accordance with a fidelity to content operates as a ritual through which the imperial vision is surreptitiously confirmed not merely through the inscription of the values of the imperial culture on the foreign text, but through the implicit denial of the possibility of differing versions of "content."

Translation practiced in accordance with the notion of the primacy and transparency of content offers further confirmation of the objectivity of the imperial vision of reality by facilitating the construction of continuities across cultures and time. Domesticating translation creates the impression of continuity by suppressing aspects of the source language text that are foreign to the target language literature, thereby implying that the source language text contains nothing genuinely unfamiliar. The source language text is valuable not as a work that has exerted an influence on the target language literature (on the contrary the poetics of the target language shaped the "original" by dictating the terms of translation), but rather as evidence of the universality of the target language literature, and continuity figures not as a consequence of cross-cultural transfer so much as a corollary to the complete adequacy of the imperial culture. Harold Bloom's The Western Canon, the fundamental assumption and thesis of which is the continuity of Western culture (literature) as reflected in its canonical works, is exemplary. While Bloom posits continuity across languages, he gives scant attention to issues of translation, usually little more than mention of the specific translations from which he draws his citations with no (or evasively subjective) explanation. In the case of Dante he uses John D. Sinclair's 1961 translation, with no mention of what is lost (or possibly gained) in the change from verse to prose. He cites from Donald M. Frame's translation of the essays of Montaigne, which he characterizes simply as "eloquent," adding that Frame is, in his view, "Montaigne's best interpreter" (49). Writing on Molière's The Misanthrope, he describes the play as a work of "shocking vitality ... a kind of violent scherzo from beginning to end" (160). This aspect of the play, he contends, is best conveyed by Richard Wilbur's translation. In the chapter on Faust he uses the translation by Stuart Atkins, which he describes as "the most accurate English version" (222), though again he makes no mention of what is lost in the shift from rhyming stanzas to what is essentially free verse. Whatever the merits of the translations Bloom has chosen, one can hardly base contentions concerning continuity across languages on an appeal to their eloquence or accuracy without at least making explicit (and thereby situating as ob- 
jects of scrutiny) the criteria on which these judgments are based. One can only accept Bloom's description of Atkins' translation as the "most accurate", for instance, if one dismisses rhyme as inessential, but a free verse rendering of Faust may lose much of the humor and irony of the original. In his preface to his translation of The Misanthrope and Tartuffe Wilbur comments that, "Moliére's logic loses all its baroque exuberance in prose; it sounds lawyerish; without rhyme and verse to phrase and emphasize the steps of its progression, the logic becomes obscure like Congrève's" (cited in Wechsler, 88). Bloom describes the The Misanthrope as a scherzo, and Faust can also be said to contain elements of scherzo, including humor and sudden changes of pace, but as in the case of Molière, without rhyme and meter buffoonery may be more tedious than amusing. In the original German the Director expresses his concerns regarding the audience with a comic mix of scorn and simpering:

Ich weiß wie man den Geist des Volks versöhnt;

Doch so verlegen bin ich nie gewesen;

Zwar sind sie an das Beste nicht gewöhnt,

Allein sie haben schrecklich viel gelesen (10, lines 43-46).

The tense apprehension and clownish officiousness is somehow lost in the free-verse rendering:

I know what counts for popularity, and yet I've never been quite so uneasy of course they are not used to anything first-rate, but still they've done an awful lot of reading (3, lines 43-46).

Atkins' text has neither the quick pulse of the original nor its ironic contrast between strict adherence to form and everyday phrasing. "An awful lot" may be excellent as a translation of "schrecklich viel," a similarly colloquial choice of words, but without rhyme to punctuate the thought the Director's complaint is more tiresome than funny, and the reader may feel increasingly eager for the whole "Prelude on Stage" to come to an end. One could cite other examples from the opening lines of the play, such as the switch in the first-person pronoun from object to subject in Atkins' translation of "Ein Schauer faßt mich" (6, line 29), which might be translated as "A dread seizes me," but for which Atkins offers "I feel a sense of dread" (1, line 29), or the change from an active to passive voice in his translation of "Das strenge Herz es fühlt sich mild und weich" (6, line 30) as "my rigid heart is tenderly unmanned" (1, line 30$)$. The point, however, is not to contest Bloom's choice of translation, and certainly not to dismiss the possibility of cross-cultural influence, but rather to suggest the importance of making explicit the criteria on which his characterization of a particular translation as "the most 
accurate" is based. When compared with the original or a varying translation, a translation adduced as an example of continuity across cultures may well seem more an example of rupture.

Bloom's unwillingness to broach the complexities of translation, while nonetheless relying on translations as the basis for his postulate of continuity, is mirrored by the absence of the study of translation from curricula in institutions of post-secondary education, an absence all the more conspicuous given the centrality of texts in translation to the humanities, where they often constitute the majority of the readings in literature and philosophy to which an undergraduate or even graduate student is exposed. The assumed superfluity of questions of translation is perhaps nowhere more apparent than in the syllabi for courses on Western literature. While most of the readings for such courses are drawn from literatures other than English, little mention is made of translation beyond the specification of a particular text for use in the course. This is not merely a convenient means of addressing the fact that students rarely have shared knowledge of one or more foreign languages, nor is it simply a question of the availability of texts. One could easily include, in lieu of a single, contemporary translation, several translations distant in time and approach as a means of suggesting the centrality rather than the marginality of the act of translation in the study of other cultures and eras. The autumn 2010 syllabus for the "Literature Humanities" course at Columbia University, for instance, which forms part of the so-called "Core Curriculum" required of students in all disciplines (the syllabus can be downloaded from the university's website), could include, alongside Lattimore's translation of Homer, at least excerpts from the translations by Chapman, Cowper, or Pope, or, alongside Allen Mandelbaum's translation of the Aeneid, (at least excerpts from) the translation by Dryden. Yet even in the case of required readings of books from the Old Testament, for which there are countless radically differing English translations, only one version is given (the Revised Standard Version). The syllabus for the "Literature Humanities" course is by no means exceptional, as a quick glance at the many syllabi available online for courses on Western or world literature makes clear. A successor to the efforts of John Erskine in the 1920s and 1930s to institute a great books curriculum, it bears numerous affinities with the great books courses also based on Erskine's model, such as the courses designed by Robert Hutchins and Mortimer Adler of the University of Chicago, which led to the publication of the Great Books of the Western World series in 1952 by Encyclopedia Britannica, issued again in 1990 in an expanded version. The National Great Books Curriculum, a beneficiary of funding from the National Endowment for the Humanities and the U.S. Department of Education Fund for the Improvement of Post-Secondary Education, offers a further example. The assertion made on the homepage of its website concerning the importance of "the Great Books as the primary source texts in a wide variety of undergraduate courses" (http://nationalgreatbooks.com/, 
emphasis added) notwithstanding, the vast majority of the works recommended could only be read by an undergraduate (or graduate student, or PhD) in translation, yet there is no mention whatsoever of the issue of translations.

This neglect of translation suggests that translation itself is both self-evident and monolithic in its practices and aims, in other words everyone translates with a common purpose and according to identical methods, and it would be superfluous to state or interrogate this purpose or these methods, or for that matter to consider contrasting translations. At most it is necessary to specify a particular translation, implicitly the best, with no explanation of criteria on which this choice was made (which might raise questions concerning the different contemporary functions differing translations might play). The disregard for translation in courses taught in English is complemented by the dismissal of translations as categorically inferior in literature courses taught in other languages, where the reading of a translation of Madame Bovary in lieu of the French text, for instance, might be scorned, with little acknowledgment of the possibility that the English translations may well come to play (or already have played) a more significant role in the reception of the novel among English reading audiences worldwide and the influence it has had on English literature itself. While the rejection of translation as inevitably inferior may seem to run counter to the assumption of the adequacy of translation that underlies the "Western canon" or "world literature" curricula, both imply an understanding of translation itself as a uniformly accepted and self-evident practice unworthy of critical scrutiny.

Yet even a cursory comparison of different of translations of allegedly canonical works belies this assumption. One could enumerate examples, from the prose and verse translations of Homer, Virgil, Dante, Molière, Goethe, Baudelaire, and others to the contrasting translations of works by philosophers such as Aristotle, Montaigne, or Nietzsche, but a short excerpt from a book of the Old Testament, a staple of great books courses and foundational text of so-called Western culture, suffices to illustrate the heterogeneity of translation as a practice and product. In the opening lines of the Song of Solomon as rendered in Young's allegedly "literal" translation the Shulamite says of herself, "Dark [am] I, and comely" (all versions cited are available at biblegateway.com). The same passage in the Revised Standard Version used in the Columbia Core Curriculum reads, "I am very dark, but comely[.]" The conjunctions are merely differing renderings of the Hebrew "v," translated in other passages of the Revised Standard Version as "and," for instance in the opening lines of Genesis ("hashamayim v'haaretz" is translated as "the heaven and the earth"). The reliance on a single translation with no comparison of differing versions precludes any discussion of the interpretive choices at work in the construction and maintenance of an opposition between darkness and beauty, instead attributing the opposition entirely to the original and implying the irrelevance of history in the production of meaning, an irresponsible elision and a 
paradoxical implication for a course purportedly centered around the study of historical continuities.

Little different are the world literature courses often substituted for courses on so-called Western literature in a no doubt well-intentioned but ultimately disingenuous attempt to counter Eurocentric bias. Disingenuous because, like the courses on the "great books" of the Western tradition, world literature courses give similarly scant attention to translation, assuming and implying, wherever the reading of a text not originally written in English is involved, the parity of translation and original and the adequacy of a body of texts in English as a sample of "world literature". Thus while the "great books" courses often had and have an explicit and announced western bias, world literature courses in English, if they offer no consideration of questions of translation, are themselves a tacit assertion of the sufficiency of the English language and English language literary values in the representation of global cultures.

In 1989 the notion of the universality or at least adequacy of the English language and English language culture found confirmation in an unlikely source. In The Empire Writes Back: Theory and Practice in Post-Colonial Literatures, an examination of historical forces acting on the post-colonial text and context, authors Ashcroft, Gareth, and Tiffin write on the alleged wealth of literatures in India in languages other than English:

\footnotetext{
It is frequently asserted that the work produced by contemporary writers in languages as diverse as Maratha, Bengali, Kannada, Telugu, Malayalam, etc. far outweighs in quantity and quality the work produced in English. This may well be the case, though until more extensive translations into English from these languages have been produced it is difficult for non-speakers of these languages to judge (121).
}

The authors seem to fail to realize that reliance on English translations as the basis for the assessment of literature written in languages other than English marginalizes works that may not lend themselves to translation into English. More importantly, they apparently assume the universality of the critical values on which such assessments would be based. To think of English translations of works written in Bengali, for instance, as providing sufficient grounds for any claim concerning the merits of Bengali literature is to deny the very possibility of Bengali literature having any meaning beyond what might be of interest to and readily assimilated by an English speaking readership. This view of translation implies that it is the task of non-English (or non-Western) cultures to produce works of literature amenable to translation into English in order to demonstrate their worth, instead of the task of the English reader to learn the languages of these cultures. 
If, as the citation from The Empire Writes Back suggests, translation as a practice continues to be understood in the context of English language literature as an means of producing equivalent substitutes for texts written in other languages (and thereby a tacit assertion of the irrelevance of any cultural difference resistant to translation), the study of translation in the Hungarian literary tradition offers examples of contrasting views of translation reflecting very different conceptions of cultural otherness. Perhaps most fundamentally, in contrast to the repeated assertions of the importance of fluency in translation in the English context, in the Hungarian tradition one finds, in the works of authors whose fiction and non-fiction are central to the canon, frequent insistence on the role of translation as a means of enriching the target language through the introduction of new expressions, forms, and ideas, as well as new conceptions of literature itself, not to the exclusion of the competing preference for fluency, but to an extent considerably more conspicuous than in English or American literature. As examples from the critical writings and translations of influential authors from the early 19th century and the first decades of the 20th illustrate, in the Hungarian literary tradition translation at times provided an alibi for breaks with convention. Furthermore, far from presenting their translations as entirely sufficient reproductions (replacements) of texts written in other languages, Hungarian translators often emphasized the difference between original and translation and hence the inadequacy of a single translation as a substitute and the incommensurability of the prevailing conventions of the target language literature and source language literature. Translation according to this conception represents an articulation rather than an effacement of distance, a distance that becomes palpable in the failure of the translation to conform to the conventions of the target language literature on the one hand and subsume the original entirely on the other.

Intellectual and literary life in Hungary at the close of the 18th century and throughout the first decades of the 19th was marked by the efforts of the so-called language reformers to mold several different dialects into a standardized language and introduce words perceived as necessary in order for Hungarian to serve as a potential language of state. The role played by translation was crucial in their efforts to enrich (or at least increase through the introduction of innumerable neologisms) the language itself and nurture the development of a literary tradition distinctive but not isolated from the other literatures of Europe. In this context, translation was often explicitly regarded as a means of addressing alleged inadequacies of the language, what was characterized by leading language reformer and prolific translator Ferenc Kazinczy, for instance, as the "unpreparedness of my language" ("nyelvemnek készületlensége," 1788, 1982, 206; all translations from Hungarian are mine). In the preface to his translations of works by Sallust, Kazinczy put forward a view of translation according to which "it is nice sometimes to detect no foreign tinge in the speech, sometimes nice for the marveled foreign to shine 
through" (1836, reprinted in Józan 2008, 143). In an essay entitled “On Translation" poet János Batsányi, one of Kazinczy's contemporaries, wrote that it would be a mistake to reproach a translator for using words foreign to the target language in order to express ideas in the foreign text, adding "this by no means corrupts, but rather enriches our language" (105). In Batsányi's view, "we can indeed borrow from the beauties of the more polished languages [pallérozottabb nyelvek] ... Our language has already profited no small amount [from such borrowings]" (106). Echoing this sentiment, fellow language reformer Pál Szemere contended that "we sometimes enrich our language by imitating the original" (193).

Many of the translations of the language reformers embody this view of translation as an instrument of innovation. Rather than affirm or maintain prevailing convention by subjecting the foreign entirely to domestication, they remained conspicuous for their failure to conform to stylistic norms and even rules (or conventions) of grammar. Kazinczy's translation of Ossian introduces archaic spellings (or rather mimicries of archaic spellings), neologisms, and unusual syntax, for instance in the excerpts below, which are followed by the corresponding passages from the original:

Zengjétek a dalt, s nyújtsátok a csigát! a palotát hadd lakja öröm. Ha te is megaggasz, napja az égnek, ha te is elmúlsz, szép ragyogvány, ha olly tartatlan a te fényed is mint a Fion fénye: úgy a te dicsedet túléli az enyém! (208)

Raise the song, send round the shell: let joy be heard in my hall. When thou, sun of heaven! shalt fail; if thou shalt fail, thou mighty light! if thy brightness is for a season, like Fingal; our fame shall survive thy beams (226-227).

Sok ízben láták ők Szalgárnak sírhelyét, sok ízben a sötét hajlékot, hol a fejérkeblü Kolma lakozik (32).

Often had they seen the grave of Salgar, the dark dwelling of whitebosomed Colma (287).

Így hágdala ő hőseiknek előtte Szelma felé a fenyéren. Menj, Ullin, menj a bék szelíd dalával (211).

He moved towards Selma; his thousands moved behind him. Go, with a song of peace, said Fingal: go, Ullin (228).

S te azzal szóllasz, Bárdja Morvának, aki rémlélek fegyverben (213).

"Dost thou speak to the weak in arms!" said Carthon, "bard of the woody Morven?" (229) 
One could mention, as concrete examples of deviation from common practice, the neologisms "megaggasz," a verb based on the adjective "agg" (old or aged), and "rémlélek," a compound noun based on the words "rém" (specter, apparition) and "lélek" (soul). "Megaggasz" was never to become part of the Hungarian language, but "rémlélek" was later used by poet Mihály Vörösmarty (author of a poem entitled Szózat, or Appeal, commonly referred to as Hungary's second national anthem) in his poem $A$ Rom (The Ruin), novelist Jókai Mór in a work of short fiction entitled $A$ két halott (The Two Dead), and Zsigmond Ács's translation of the Merchant of Venice. One could also note the words "bék" instead of "béke" (peace) and "fejérkeblü" instead of "fehérkeblü" (white-bosomed) as examples of non-standard spelling. This is particularly significant in a work by Kazinczy, who otherwise was an advocate of standardization. The deliberate use of non-standard spelling seems specifically intended to conjure an impression, however artificial, of distance and otherness, reminding the reader that the text is not an "original," as it were, but a translation.

The translation of extensive passages from the Iliad by Ferenc Kölcsey, for a time a prominent member of the language reform and author of a poem that became the text of the Hungarian national anthem, offers another example of translation as a pretext for failure to conform to common practice. Like Kazinczy's translation of Ossian, Kölcsey's Iliad contained spellings and grammatical constructions unusual in the Hungarian of the early 19th century. For instance, in the opening passages of the second book, Zeus sends a dream to deceive Agamemnon (Kölcsey's translation is available at wikisource.org):

S a több égi lakók és hadviselő lovaghősek

Nyugtak egész éjjel; csak Zevstől fut vala az alvás,

Mert neki gondjai közt hánykódik szíve, Achilevst mint

Tisztelje, és hozzon görögökre halált a hajóknál.

S nékie lelkében e szándék tetsze leginkább:

Hős Agamemnonnak gonosz álmot küldjön elébe[.]

…

Így szólt. Méne pediglen az Álom, hogy érti parancsát,

$\mathrm{S}$ hirtelen eljuta gyors gályáihoz a görögöknek,

S ment Agamemnonra, őt pedig elszunnyadva találá

Termén, s ambroziás álom vala ömölve körülte.

This passage, in Samuel Butler's translation, reads:

The dream went when it had heard its message, and soon reached the ships of the Achaeans. It sought Agamemnon son of Atreus and found him in his tent, wrapped in a profound slumber. [...] The dream went when it had heard its message, and soon reached the ships of the Achaeans. It sought Agamemnon son of Atreus and found him in his tent, wrapped in a profound slumber (14). 
Szemere praised Kölcsey's translation, mentioning specifically his use of the letter "v" instead of "u" in proper names ("Zevs", "Achilevst", etc.) and the participial endings -ve and -va, for instance on the verbs elszunnyad (doze off) and ömöl (pour) in the last two lines (could be translated, "It went to Agamemnon and found him dozing off in his chamber, an ambrosia dream poured all around him"). The participial endings are equivalent to -ing in English ("running", "standing", etc.), a form that came into Hungarian largely through the influence of Latin and remains a bit foreign to this day. It has become part of common speech in many expressions, such as "sírva fakad" ("he/she burst out crying"), but nonetheless is used considerably less frequently than in English (one would not say, "hallottam énekelve", in English "I heard him/her singing", but rather would simply use the infinitive, which always ends in -ni, "hallottam énekelni"). According to Szemere, "a poet like Homer, who in the time of Herodotus was already the child of a distant era, ... loses all his distinctiveness as soon as the hue of antiquity is no longer discernible in the copies [of his works] in another language: here epoch and language and poet are inseparable" (195). The translation was valuable because "[Kölcsey] has brought the era of the language of the original into his translation. ... [He] has asked ... how Homer would have given his heroes voice in the era of Latiatuc" (195; "Latiatuc" is a reference to the Halotti beszéd és könyörgés, or "Funeral speech and prayer," the earliest known text in Hungarian, dated to the last decade of the 10th century). Writing almost a century later, Jenő Vértesy, author of a biography of Kölcsey, offered a similar assessment. "His translation is often un-Hungarian [magyartalan] and makes ill use of liberties in versification", he wrote. "But Kölcsey was never vacuous, and here too he did something significant: he wanted to give the language an archaism ... that would take one back to the naïve world of pastors and warriors. Kölcsey failed, but he showed the path that [other poets] later followed with such glory" (62).

In the first decades of the 20th century Hungarian literature went through a period of innovation and even upheaval similar in many ways to the transformations of the era of the language reform. The most influential literary periodical, Nyugat, was explicit about its orientation to the west, and its pages were filled with translations from western languages, often including polemic articles concerning the alleged merits and shortcomings of specific translations. The craving for something new found expression in an essay by Lajos Hatvany, published in Nyugat in 1908. Lamenting what he perceived as the stagnation of literature in Hungary, he complained that too often Hungarian authors were encouraged to seek their models in the traditions of the past. "Just don't mention the whole of that past", he wrote, "but rather show me, among the many poets, the one man, the one era, the one great or unusual figure in whom the artist can seek moving elements. I fear it will be hard! I believe we are living through a time like the end of the 18th and the be- 
ginning of the 19th century: there is nothing to seek here at home, we must look to our neighbors" (569).

In this context it is perhaps hardly surprising that one finds, in the writings of some of the most prominent authors of the time, conceptions of translation similar to those of Kazinczy, Szemere, and Batsányi. In an article on the difficulties of translating Dante and the weaknesses of an existing Hungarian translation, Mihály Babits, poet, novelist, and himself translator of Dante (as well as Shakespeare, Baudelaire, Keats, Swinburne, and numerous others), wrote "literary translation is an entirely separate path to the enrichment of language - and thereby of thought, of all of mental life - something the literature relying only on itself would never lead to" (663). Literary translation, in his view, "forces into new channels the manner of thinking of a people which until then had only been able to move down the familiar corridors of its language and could hardly have sensed anything else" (663). Babits regarded the publication of a fine translation as "an epoch-marking date in the history of a language," noting that the translations into Hungarian of the Bible, Aristophanes, Boccaccio, Shakespeare, and others "gave new locutions, new possibilities, new music, and even new contents to the Hungarian language" (663). Dezső Kosztolányi, Babits's contemporary and the most prolific translator of his generation, insisted - in marked contradistinction to the implication of parity between translation and original prevalent in the English and American traditions - on the difference between translation and original. "My literary translations do not correspond to the originals like a painting corresponds to the copy of a painting", he wrote, "but rather as a painting corresponds to the object it depicts" ( 531).

Babits's translations are too numerous and varied to permit easy generalization, but in them one comes across spellings, words, phrases, and images that seem distant from the Hungarian literature of his time. His translation of Keats The Eve of St. Agnes offers several examples (the first three stanzas of which are given below, followed by the first three stanzas of the original):

Mi lelhetett, szegény fiú?

Magadba bolygasz, sáppadón. -

Madár se zeng már, kókadoz

A nád a tón.

Mi lelhetett, szegény lovag?

hogy arcod bánattal csatás?

A mókus csőre tellve, kész

Az aratás.

A homlokodon liliom, lázharmat, nedves fájdalom: 


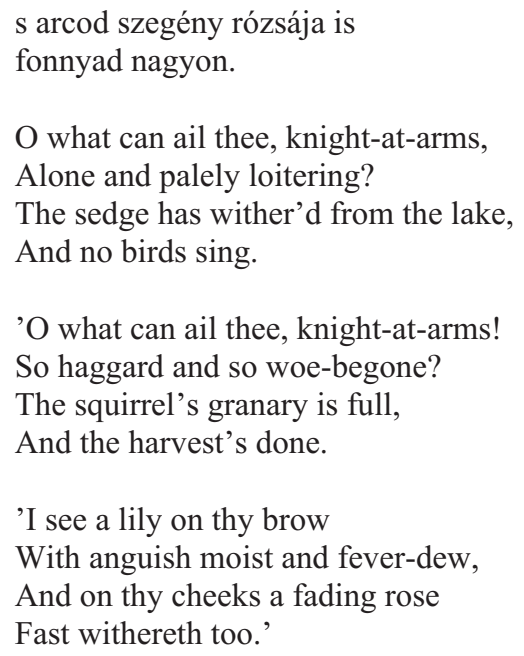

As the very free translation of "knight-at-arms" as "szegény fiú" ("poor boy") makes clear, Babits was not constrained by the original, yet neither did he seek to remove all trace of remoteness from the poem. "Lázharmat," for instance, is a neologism, a literal rendering of "fever-dew," but more conspicuously, the verb and adverb in the second line ("bolygasz" instead of the more standard "bolyongsz" as the translation of "loiter" and "sáppadón" instead of "sápadtan" as the translation of "palely") manufacture an impression of distance, perhaps in time, perhaps in social register, not present in the original.

Translations by poet Endre Ady, another member of the so-called Nyugat generation, of three poems by Charles Baudelaire offer similar examples of translation as departure from the conventions of Hungarian literature of the early 20th century. The unusual publication history of the poems itself suggests shifting conceptions of translation as recreation or simulation. As Hungarian literary historian János Korompay has noted, Ady first published his translations of Baudelaire's La Destruction and La Cloche fêlée anonymously in the literary periodical Budapesti Napló (Budapest Journal) in October 1904, followed two weeks later by the publication of his translation of Causerie, this time with his name as translator (Korompay, 624). In the case of the first two poems Ady gave his translations Hungarian titles, Pusztulás and Repedt harang, while his translation of Causerie was simply published under the French title. This omission could be interpreted as an indication of the difficulty (if not impossibility) of translating the French title, which in English has been translated as "Conversation" by several translators (though Edna St. Vincent Millay preferred "Episode"). Neither "conversation" nor the Hungarian "beszélgetés" (perhaps the most immediately obvious translation of the French) bears the same connotations of casual familiarity as 
"causer" and "causerie", connotations that suggest the closeness of the relationship between the poet and beauty. But more interestingly, Ady's failure to translate the title proclaims rather than conceals the status of the poem as a translation. However the interpretive choices made in the act of translation may (or may not) have led to the assimilation of the French text to the values and conventions of Hungarian literature, no attempt is made to obscure the fact that the resulting Hungarian text is a translation. Furthermore, while the anonymous publication of the first two translations presents the poems simply as the work of the French poet, the inclusion of Ady's name as translator in the case of Causerie represents an acknowledgement of his role in their authorship and implicitly their difference from the originals on which they were based. This may seem trivial, given that it was common practice to include the name of the translator, but in 1905 Ady further emphasized the difference between original and translation by publishing the three translations in a volume entitled $U_{j}^{\prime} j$ versek (New poems), which consisted primarily of original poems, but also, alongside the Baudelaire poems, translations of works by Verlaire and Jehan Rictus. The translations were referred to simply as "Három Baudelaire-szonett" (Three Baudelaire sonnets), "Paul Verlaine álma" (Paul Verlaine’s dream), and "Jehan Rictus strófáiból" (From the strophes of Jehan Rictus). As Ildikó Józan has observed, the use of the possessive implies, in lieu of a first-person "I" author-figure, a third person "he" who cannot be identified as the origin of the poems. The texts figure not as the unmediated utterances of the original author, "but rather as a direct or indirect citation of such an utterance or an evocation of an understanding or interpretation connected in some way to the original author's name" $(2007,59)$. Thus with each publication the figure of the translator gained prominence, as did the incommensurability of translation and original.

In the context of the Hungarian literature of the turn of the century, the three Baudelaire sonnets are unusual in their imagery, their syntax, and arguably their eroticism. Below is Ady's translation of Causerie, followed by the original and the English translation by Edna St. Vincent Millay:

Vous êtes un beau ciel d'automne, clair et rose! Mais la tristesse en moi monte comme la mer, Et laisse, en refluant, sur ma lèvre morose Le souvenir cuisant de son limon amer.

Ta main se glisse en vain sur mon sein qui se pâme; Ce qu'elle cherche, amie, est un lieu saccagé Par la griffe et la dent féroce de la femme. $\mathrm{Ne}$ cherchez plus mon coeur; les bêtes l'ont mangé. 
Mon coeur est un palais flétri par la cohue;

On s'y soûle, on s'y tue, on s'y prend aux cheveux!

Un parfum nage autour de votre gorge nue!...

Ô Beauté, dur fléau des âmes, tu le veux!

Avec tes yeux de feu, brillants comme des fêtes,

Calcine ces lambeaux qu'ont épargnés les bêtes!

Büvös, szép őszi ég vagy, tündöklés, rózsaszirom.

Bennem a szomorúság tengere sírva árad

$\mathrm{S}$ ha visszafut, otthagyja fanyar, bús ajkaimon

Maró emlékezetét keserú iszapjának.

Kezed hiába csúszik alélt keblemen tova,

Amit keres, barátnőm, marcangolt hely, üres rég,

Széttépte azt az Asszony vad karma, éhes foga,

Óh, ne keresd a szívem, az állatok megették.

Palota volt a szívem s a tömeg befertőzte,

Most benne orgiáznak, gyilkolnak, civódnak ott.

Meztelen kebled körül parfüm szálldos felhőzve.

Lelkek kemény korbácsa, óh, Szépség, Te akarod. Lobbantsd fel ünneppiros lángjával tüzszemednek A rongyokat, amiket a rablók itt feledtek.

You are a lovely, rosy, lucid autumn sky!

But sadness mounts upon me like a flooding sea,

And ebbs, and ebbing, leaves my lips morose and dry,

Smarting with salty ooze, bitter with memory.

Useless to slide your hand like that along my breast;

That which it seeks, my dear, is plundered; it is slit

By the soft paw of woman, that clawed while it caressed.

Useless to hunt my heart; the beasts have eaten it.

My heart is like a palace where the mob has spat;

There they carouse, they seize each other's hair, they kill.

Your breast is naked... what exotic scent is that?...

O Beauty, iron flail of souls, it is your will!

So be it! Eyes of fire, bright in the darkness there,

Bum up these strips of flesh the beasts saw fit to spare.

Readers and critics were quick to praise what they perceived as the innovativeness of the poems of the volume, but without necessarily acknowledging (and as Józan notes, perhaps without realizing) that some of them were transla- 
tions $(2009,241)$. In a letter to Ady, former schoolmate Oszkár Jászi wrote of how pleased he had been to read "such things in Hungarian. And moreover original poems, not imitations" (cited in Ágh 2007; emphasis added). Lajos Biró cited the first four lines of Ady's translation of Causerie, contending "no one has ever written like this in Hungarian", but he gave no indication that he realized the poem was a translation (cited in Józan 2009, 242). Józan contends one can read the poem as a depiction of otherness, referring to "the construction of images and the linguistic artificiality of the last stanza (the foreignness of the word order)" (61). One could also mention the affected preciousness of the phrasing, for instance "szálldos felhőzve", a phrase that could be translated (attempting to preserve its strangeness) as "ascendts, clouding", or Ady's translation of "on y soûle" as "orgiáznak" (they are having an orgy) and "gorge nue" as "meztelen kebled" (naked bosom or breast), translations that in both cases are more sexually explicit than the original and more suggestive of decadence than much of the literature of Ady's Hungarian contemporaries. A comparison with the translation by Lörinc Szabó is illustrative. Szabó translates "soûle" as "tombol," which means rave or rage and has no sexual connotations, and "gorge nue" as "tárt kebled," which replaces Ady's literal "meztelen" (naked, i.e., referring specifically to the absence of clothing) with the more general "revealed." By introducing elements of the erotic, Ady arguably violates or expands the borders of poetic language in Hungary at the turn of the century. Crucially, he does so in a translation, allowing the foreign element in the text to figure as the consequence of translation, but this "foreignness" is really the foreignness of an element of discursive practice (explicit reference to sex or nudity) to the discursive practice(s) demarcated as "poetry" at the time.

The conception of translation as a vehicle through which to introduce foreign elements into the target language, a conception exemplified by the critical writings and translations cited above, constitutes a salient difference between Hungarian literature and the English and American traditions. Unquestionably translation was no less part of a domestic agenda in the Hungarian context than Denham's assimilation of Virgil to prevailing conventions or Lamb's expurgated versions of poems by Catullus were in the English. The introduction of neologisms by leaders of the language reform, for instance, was as much (or more) an attempt to address the perceived inadequacies of the Hungarian language of the time as it was an indication of a desire to preserve the foreignness of the original text in translation. But the differences in the two views concerning the potential roles of translation nonetheless reveal differences in attitudes towards the two national cultures, entirely self-sufficient in the case of English and American literature, situated and distinctive, but not exhaustive as a view of the world or means of expression in Hungarian. Seen in a comparative context, translation emerges not as a set of prac- 
tices consistent across cultures and times, but as a form of self-representation no less historically and culturally situated than literature itself, and as such no less worthy of study.

It would be misleading, as a conclusion, to insist on the dominance of translation as innovation in the Hungarian tradition to the exclusion of preferences among translators, critics, and readerships for fluency, just as it would be misleading to insist on the dominance in contemporary literature in English of domesticating translation to the exclusion of all other approaches, but a recent example suggests that fluency continues to represent a standard of value and normative force in the canon of translation into English. In 2009 Herta Müller was awarded the Nobel Prize for literature. A member of the German speaking minority in the western region of Romania known as Banat until her emigration in 1987, Müller has written in several of her essays on the tensions between her mother tongue and the official language of the country of her birth, noting the ways in which the two languages acquire their own naturalness in the mind of the speaker while at the same time throwing each other into question. This tension is often palpable in her fiction and poetry (she has authored collections of collage poetry in German and Romanian). For instance, the title of the novel Der Mensch ist ein Grosser Fasan auf der Welt (which could be translated as "man is a big pheasant in the world"), the story of a German speaking family hoping to obtain permission to emigrate, is ambiguous. In German, the pheasant is a braggart, in Romanian, a loser (something like a turkey in English). The characters of the story are German speakers, but when they utter this phrase, the Romanian connotation prevails. The English translation by Martin Chalmers avoids this surplus of meaning entirely, replacing the ambiguous German with the supremely rational title Passport. Müller's Herztier (which could be translated as "heart beast") was translated by Michael Hofmann as The Land of Green Plums. The title of Müller's most recent novel, Atemschaukel ("Breath-Swing"), has simply been replaced with the English translation of the first sentence of the story (itself a German translation of the Latin "mea mecum porto"): "Everything I Possess I Carry With Me" (the novel still awaits translation into English, but this is the English title in use at the moment). Neither Der Mensch ist ein Grosser Fasan auf der Welt nor Herztier has been translated into Hungarian yet, but the title of the Hungarian translation of Atemschaukel, Lélegzethinta by Lídia Nádori, preserves the strangeness of the German compound word. The striking inventiveness of Müller's use of language, no doubt in part a product of her bilingual background, is effectively translated out of the English titles in order to bring them into conformity with the utilitarian conception of language as an incidental tool of signification. The Nobel Prize, one of the most powerful tools in the construction of a canon of world literature, guar- 
antees either the prompt translation of the works an author into English or, where English translations are already available, their spread among diverse (and often multilingual) English reading communities. One cannot help but wonder whether the insistence on "logical" renderings and the avoidance of ambiguity in the English translations will contribute to an impoverishment of this "world" literature by encouraging the reading of works of literature as simple repositories of uncontested meaning.

\section{Works cited}

Ágh, István. “'Régi, vén, falusi gyerek.’ Ady Endre idézése.” Kortárs, 2007/06. (available online: http://www.kortarsonline.hu/0706/agh.htm.)

Arnold, Matthew. On Translating Homer: Three Lectures Given at Oxford. London: Longman, Green, Longman, and Roberts, 1861.

Ashcroft, Bill, Griffiths, Gareth, Tiffin, Helen. The Empire Writes Back: Theory and Practice in Post-Colonial Literatures. London: Routledge, 1989.

Babits, Mihály. "Dante fordítása." Nyugat. 1912.8. Budapest: Nyugat Nyomdája. 659-670.

Batsányi János. A fordittásról. In Összes müvei. II. Prózai müvek. I. Sajtó alá rendezte Keresztury Dezső és Tarnai Andor. Budapest: Akadémiai Kiadó, 1960.

Bettelheim, Bruno. Freud and Man's Soul. New York: Knopf, 1982.

Bloom, Harold. The Western Canon: The Books and School of the Ages. New York: Harcourt Brace, 1994.

Geszner' Idylliumi, fordította Kazinczy Ferenc, Kassa, Füskuti Landerer Mihály, 1788. Modern kiadás: Érzelmes Históriák, válogatta, szerkesztette, jegyzetekkel ellátta Lőkös István. Budapest, Magvető Könyvkiadó, 1982 (Magyar Hírmondó), 205-355.

Goethe, Johann Wolfgang. Faust: Eine Tragödie. Tübingen. J. G. Cotta'sche Buchhandlung, 1808.

Goethe, Johann Wolfgang. Faust I and II. In: Goethe: The Collected Works. Vol. 2. Edited and translated by Stuart Atkins. New Jersey: Princeton University Press, 1984.

Hatvany, Lajos. "Szimat és ízlés.” Nyugat. 1908.10. Budapest: Nyugat Nyomdája 568-570.

Homer. The Iliad of Homer. Translated by Samuel Butler. Forgotten Books, 2007 (1898).

Józan, Ildikó. Baudelaire traduit par les poètes hongrois: vers une théorie de la traduction. Paris: Presses Sorbonne Nouvelle, 2009.

Józan, Ildikó. "Irodalom és fordítás." A magyar irodalom történetei. III, 52-68. Eds. Szegedy-Maszák, Mihály; Veres, András. Budapest: Gondolat Kiadó, 2007.

Kazinczy, Ferenc. C. C. Sallustius’ épen maradt minden munkái. Bevezetés. Magyarra fordította Kazinczy Ferencz. Buda. Kiadja a’ Magyar Tudós Társaság. 1836. Reprinted in Józan, Ildikó. A müforditás elveiröl. Budapest: Balassi Kiadó, 2008. 142-143.

Kazinczy, Ferenc. Kazinczy Ferenc Munkáji. Pest: Szép Literatúra, Trattner János Tamásnál, 1815.

Korompay, János. “Ady Baudelaire fordításai.” Irodalomtörténeti Közlemények. 81. évfolyam 4-6. sz. 1977. 622-636.

Kosztolányi, Dezső. "Modern költők: Előszó az első kiadáshoz." Reprinted in Idegen költők. Ed. Réz, Pál. Budapest: Szépirodalmi Könyvkiadó, 1988 (1913). 529-521.

Lamb, Charles. The Poems of Caius Valerius Catullus. London: Printed by Thomas Davison, Whitefriars, 1821. 
Lefevere, André. Translation/History/Culture. Routledge. New York, 1992.

Macpherson, James. Poems of Ossian. Boston: Phillips, Sampson and Company. 1851 [Reprint of the 1773 edition].

Szemere, Pál (1826). "A fordításról.” Reprinted under the title "A múfordításról” in Szemere Pál Munkái. II. Ed. József Szvorényi. Budapest. 1890. 192-195.

Venuti, Lawrence. The Translator's Invisibility. Routledge. New York, 1995.

Vértesy, Jenő. Kölcsey Ferenc, 1790-1838. Ed. Lajos Dezső. Budapest. A Magyar Történelmi Társulat, 1906.

Wechsler, Robert. Performing without a State: The Art of Literary Translation. Catbird Press, 1998. 